\section{Funder moves to quell Turkish censorship row}

The publisher of Turkey's most popular science magazine, Bilim ve Teknik (Science and Technology), has resolved a headlinehitting dispute over the magazine's apparent censorship of an article about Charles Darwin (see Nature 458, 259; 2009). The row was politically charged because the magazine is published by TÜBİTAK, the national science-funding agency.

The agency's vice-president, Ömer Cebeci, withdrew a cover and 16-page feature devoted to Darwin just before the March issue went to press. He claimed that the editor, Çiğdem Atakuman, had secretly changed previously agreed content, and he told her that she would be transferred to another department. TÜBİTAK has now issued a statement confirming its commitment to science and scientific literacy in the country, where many people do not believe in evolution. Atakuman will remain as editor of the magazine.

\section{Marine sequencing project embarks on another cruise}

Scientists from the J. Craig Venter Institute have reboarded the research sloop Sorcerer II to sample microbes from the Baltic, the Mediterranean and the Black seas. The microbes will be frozen and sent back for DNA sequencing at the institute's labs in Rockville, Maryland, and San Diego, California.

Craig Venter and his colleagues have already circled the globe to collect openocean microbes (Nature 446, 240-241; 2007). The new voyage, which commenced on 19 March, will "give us substantially more diversity than we find in the open oceans of the world", says Venter.

Flanked by dense human populations, the three seas are likely to paint a portrait of human effects on microbial populations, he says. The project is expected to cost around US\$10 million and will be funded by the Beyster Family Foundation in San Diego, with additional grants from-

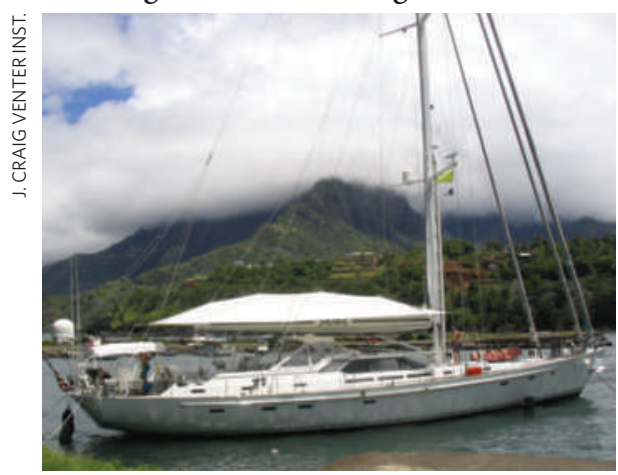

Setting sail: Sorcerer II is heading out to sea again.

\title{
Flames burn higher in Pacific 'ring of fire'
}

A volcano in the Tonga archipelago has destroyed all plant and animal life on the island of Hunga Ha'apai, according to a survey of the area.

The volcano, which began erupting on 16 March, is sited 63 kilometres northwest of the Tongan capital, Nuku'alofa. Concern grew on 20 March when a magnitude-7.9 earthquake some 210 kilometres southeast of Nuku'alofa led to tsunami warnings for all residents within 1,000 kilometres of the epicentre.

Although the tsunami warning was later cancelled, scientists have warned that the quake could lead to more lava flowing from the volcano's two vents: one situated on the island, the other just offshore.

Meanwhile, on the other side of the Pacific 'ring of fire' - the chain of volcanoes that skirts the Pacific Ocean - Mount Redoubt in Alaska erupted on 22 March, throwing huge plumes of ash into the sky.

anonymous donors and Life Technologies, the biotechnology company formed from the merger of Invitrogen and Applied Biosciences.

\section{US medical institute to set up African research centre}

The Howard Hughes Medical Institute (HHMI) in Chevy Chase, Maryland, last week announced the setting-up of its first research laboratory outside the United States. The KwaZulu-Natal Research Institute for Tuberculosis and HIV in Durban, South Africa, will operate in partnership with the University of KwaZulu-Natal and will focus on the increasing incidence of tuberculosis in those infected with HIV.

One in ten individuals worldwide is infected with Mycobacterium tuberculosis, the bacterium that causes the disease, but it does not usually cause full-blown disease. However, $M$. tuberculosis can be devastating in individuals whose immune systems are weakened by HIV. South Africa accounts for almost one-fifth of the global HIV disease burden, and tuberculosis, including multi-drug-resistant and extensively drugresistant strains, is a major problem there. The HHMI will invest US\$60 million in the centre over the next decade, and will bring in the cream of its international scientists to help train local researchers.

\section{US panel to guide treatment comparison}

The 15-person committee that will oversee the spending of US $\$ 1$.1 billion on 'comparative effectiveness' research was

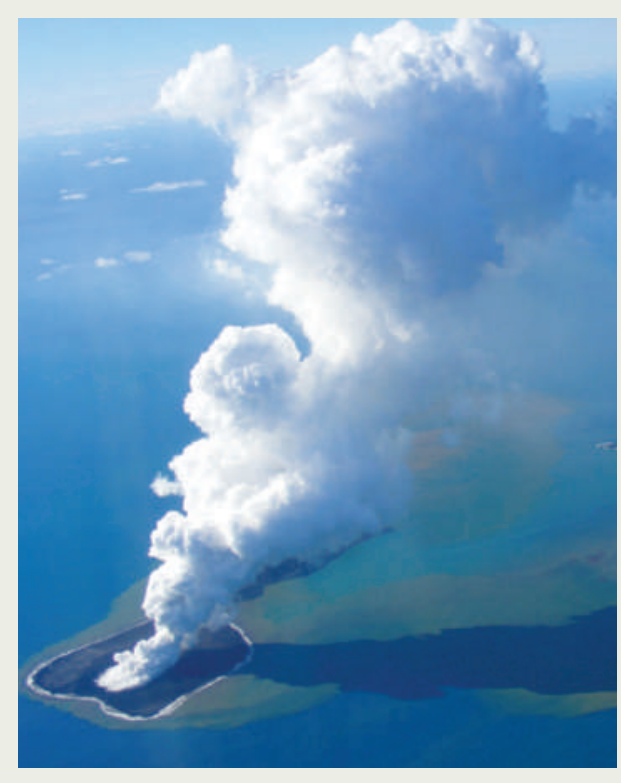

named by the US Department of Health and Human Services on 19 March. Elizabeth Nabel, director of the National Heart, Lung and Blood Institute in Bethesda, Maryland, will represent the National Institutes of Health, which is receiving $\$ 400$ million of the money.

Over the next 18 months, the initiative will support research by federal agencies on the relative strengths and weaknesses of various medical interventions, ideally providing physicians and patients with the information needed to drive cost savings in the world's most expensive health-care system (see Nature 458, 7; 2009). It was funded as part of the \$787-billion economic stimulus package signed into law in February.

\section{Science head of energy department is named}

Steven Koonin, the former provost of the California Institute of Technology in Pasadena and current chief scientist of global energy company BP, has been selected by US President Barack Obama to serve as undersecretary of science at the Department of Energy. Koonin would replace Raymond Orbach in overseeing the department's \$4.7-billion science portfolio, including running the national laboratory system. The position requires Senate confirmation.

The appointment had been rumoured in Washington for some time; Koonin is a long-time colleague of Steven Chu, the new energy secretary. Both played a major part in setting up a \$500-million industry-university alliance between $\mathrm{BP}$, the University of California at Berkeley and the University of Illinois at Urbana-Champaign. 